\title{
PENENTUAN PENGARUH KUALITAS TANAH DAN AIR TERHADAP PRODUKSI TOTAL TAMBAK POLIKULTUR UDANG VANAME DAN IKAN BANDENG DI KABUPATEN LAMONGAN, PROVINSI JAWA TIMUR MELALUI APLIKASI ANALISIS JALUR
}

\author{
DETERMINATION OF EFFECT OF SOIL AND WATER QUALITY TO TOTAL \\ PRODUCTION OF POLYCULTURE WHITE SHRIMP AND MILK FISH PONDS IN \\ LAMONGAN REGENCY, EAST JAVA PROVINCE \\ THROUGH PATH ANALYSIS APPLICATION
}

\author{
Erfan Andi Hendrajat*, Erna Ratnawati, dan Akhmad Mustafa \\ Balai Riset Perikanan Budidaya Air Payau dan Penyuluhan Perikanan, Sulawesi Selatan \\ *E-mail: erfanhendrajat67@gmail.com
}

\begin{abstract}
Soil and water quality are the factors that determine the brackishwater ponds total production in Lamongan Regency, East Java Province. This research aimed to determine direct effect and indirect effect of soil and water quality on total production of brackishwater ponds policulture of white shrimp and milkfish productivity in Lamongan Regency. The research was conducted in brackishwater ponds of Glagah, Karangbinangun, Turi, Sukodadi, Karanggeneng, and Maduran Subdistricts, Lamongan Regency. Soil quality was defined as independent and exogenous variables; water quality as an intermediate, dependent and endogenous variables; and total production as dependent and endogenous variables. Characteristics of soil and water quality as well as the total production is known through descriptive statistics application, while the effect of soil and water quality on total production is known through path analysis applications. The results of path analysis showed that 15 soil quality variables analyzed was only 2 variables that affect on total production, namely: $p H_{K C L}$ and $\mathrm{Al}$, and 11 water quality variables analysed only 2 variables that affect on total production namely: $D O$ and $\mathrm{pH}$. $\mathrm{pH} \mathrm{H}_{\mathrm{KCL}}$ of soil has significant effect with direct effect of 0.314 on total production, while Al has hightly significant effect with direct effect of -0.426 on total production. DO and $\mathrm{pH}$ of water have direct effect of -0.367 and -0.245 on total production, respectively.
\end{abstract}

Keywords: path analysis, soil, water, brackishwater pond, policulture, Lamongan Regency

\begin{abstract}
ABSTRAK
Produktivitas polikultur udang vaname dan ikan bandeng dipengaruhi oleh faktor kualitas tanah dan air tambak. Penelitian ini bertujuan untuk mengetahui pengaruh langsung atau tidak langsung kualitas tanah dan air terhadap produksi total pada tambak polikultur udang vaname dan ikan bandeng di Kabupaten Lamongan dengan menggunakan analisis jalur. Penelitian dilaksanakan di kawasan tambak Kecamatan Glagah, Karangbinangun, Turi, Sukodadi, Karanggeneng, dan Kecamatan Maduran, Kabupaten Lamongan. Kualitas tanah ditetapkan sebagai peubah bebas dan eksogen; kualitas air sebagai peubah perantara, tergantung dan endogen; serta produksi total sebagai peubah tergantung dan endogen. Karakteristik lingkungan diketahui melalui aplikasi statistik deskriptif, sedangkan pengaruh faktor lingkungan diketahui melalui aplikasi analisis jalur. Hasil penelitian menunjukkan bahwa produksi total tambak polikultur udang vaname dan ikan bandeng di Kabupaten Lamongan dipengaruhi secara nyata oleh 2 peubah dari 15 peubah kualitas tanah dan 2 peubah dari 11 peubah kualitas air. Peubah kualitas tanah meliputi $\mathrm{pH}_{\mathrm{KCL}}$ tanah dengan pengaruh langsung sebesar 0,314 dan Al tanah sebesar $-0,426$, sedangkan peubah kualitas air meliputi DO dengan pengaruh langsung sebesar $-0,367$ dan $\mathrm{pH}$ air sebesar -0,245 terhadap produksi total.
\end{abstract}

Kata kunci: analisis jalur, tanah, air, tambak, Polikultur, Kabupaten Lamongan 


\section{PENDAHULIAN}

Kabupaten Lamongan merupakan salah satu produsen udang vaname terbesar di Jawa Timur. Bersama dengan bandeng, udang vaname merupakan komoditas utama di wilayah ini. Pada tahun 2010, produksi udang vaname mencapai 1.911 ton atau $52,99 \%$ total produksi perikanan budidaya di Kabupaten Lamongan. Penyebaran yang cepat dari usaha budidaya udang vaname disebabkan oleh beberapa faktor, diantaranya adalah reproduksi yang lebih cepat, udang vaname memiliki daya tahan lebih tinggi dibanding udang windu dan dapat dibudidayakan dengan kepadatan biomassa yang lebih tinggi (Andriyanto et al., 2013).

Sampai dengan tahun 2010, kegiatan pertambakan air payau di Kabupaten Lamongan seluas $1.745,40$ ha dengan produksi sebesar 3.606,022 ton, sedangkan kegiatan pertambakan air tawar seluas 23.454,73 ha dengan produksi sebesar 30.516,871 ton (Anonim, 2010). Menunjang peningkatan produksi perikanan di Kabupaten Lamongan, pemerintah setempat menetapkan beberapa lokasi kawasan minapolitan yaitu Kecamatan Glagah sebagai kawasan inti (minapolis), serta Kecamatan Karangbinangun, Kecamatan Deket, Kecamatan Lamongan, Kecamatam Turi, Kecamatan Karanggeneng, Kecamatan Brondong dan Kecamatan Kalitengah sebagai kawasan penyangga (hinterland) berdasarkan Keputusan Bupati Nomor 188/152/KEP/413. 013/2011 dan pembentukan Kelompok Kerja (POKJA) berdasarkan Keputusan Bupati Nomor 188/151/KEP/413.013/2011. Komoditas unggulan yang dikembangkan yaitu udang vaname dengan target produksi pada tahun 2011 (13.100 ton), tahun 2012 (13.352 ton), tahun 2013 (13.604 ton) dan pada tahun 2014 (13.856 ton) dengan kenaikan produksi sebesar $1,89 \%$ per tahun. Realisasi produksi udang vaname pada tahun 2012 adalah sebesar 11.100,32 ton (Anonim, 2014).

Produktivitas budidaya ikan dan udang secara alamiah tergantung pada keberadaan makanan alami dan kondisi lingkungan yang baik bagi ikan dan udang. Lingkungan tambak sangat dipengaruhi oleh faktor tanah dan air. Kemampuan untuk memanipulasi kedua faktor tersebut berpengaruh kepada produktivitas budidaya. Walaupun air adalah media langsung bagi ikan dan udang dan selalu berinteraksi di dalamnya namun tanah tetap memberikan pengaruh bagi kualitas air tempat ikan dan udang hidup di dalamnya, karena interaksi keduanya akan berpengaruh pada kualitas air (Boyd, 1995). Kualitas air tambak sangat dipengaruhi kualitas tanah dasar. Tanah dasar tambak dapat bertindak sebagai penyimpan (singk) dan sumber (source) dari beberapa unsur dan oksigen terlarut (Boyd et al., 2002; Hidayanto et al., 2004). Tanah dasar tambak juga berfungsi sebagai buffer, penyedia hara, sebagai filter biologis melalui absorbsi sisa pakan, ekskreta kultivan dan metabolit alga, sehingga tanah dasar tambak merupakan salah satu faktor penting untuk menentukan pengelolaan tambak (Murachman, 2002). Secara umum, faktor lingkungan tambak (kualitas tanah dan air) adalah faktor penentu dominan dalam budidaya tambak sehingga dipertimbangkan sebagai kriteria dalam kesesuaian lahan untuk budidaya tambak (Muir dan Kapetsky, 1988; Boyd, 1995; Treece, 2000; Salam et al., 2003; Karthik et al., 2005; Mustafa et al., 2007). Faktor lingkungan tambak adalah faktor penting yang mempengaruhi produksi di tambak (Mustafa dan Ratnawati, 2005; Mustafa dan Sammut, 2007). Oleh karena itu dilakukan penelitian yang bertujuan untuk mengkarakteristik tanah dan air tambak serta mengetahui pengaruh langsung atau tidak langsung kualitas tanah dan air terhadap produksi total pada tambak polikultur udang vaname dan ikan bandeng di tambak Kabupaten Lamongan melalui aplikasi analisis jalur dalam upaya meningkatkan pendapatan pembudidaya dan produksi udang vaname dan ikan bandeng yang merupakan komoditas unggulan budidaya perikanan. 


\section{METODE PENELITIAN}

Penelitian dilaksanakan di Kecamatan Glagah, Karangbinangun, Turi, Sukodadi, Karanggeneng, dan Kecamatan Maduran, Kabupaten Lamongan, Provinsi Jawa Timur selama dua minggu. Penelitian berupa pengambilan contoh tanah dan air serta wawancara dengan responden. Analisis kualitas tanah dan air masing-masing dilaksanakan di Laboratorium Tanah dan Laboratorium Air, Balai Riset Perikanan Budidaya Air Payau dan Penyuluhan Perikanan (BRPBAP3), Maros, Provinsi Sulawesi Selatan.

\subsection{Pengumpulan Data}

Data dikumpulkan melalui metode survei pada pembudidaya yang melakukan budidaya secara polikultur antara udang vaname dan ikan bandeng meliputi kualitas tanah dan kualitas air serta produksi total tambak. Pengambilan contoh tanah dilakukan dengan bor tanah yang dilengkapi skala. Contoh tanah diambil dan diukur sebanyak 26 sampel dengan kedalaman 0-20 cm dan 0$40 \mathrm{~cm}$. Contoh tanah yang diambil dimasukkan ke dalam kantong plastik kemudian disimpan dalam kotak contoh tanah untuk analisis peubah kualitas tanah di Laboratorium Tanah Balai Riset Perikanan Budidaya Air Payau dan Penyuluhan Perikanan, Maros, Provinsi Sulawesi Selatan. Pengukuran kualitas tanah yang dilakukan secara in situ adalah $\mathrm{pH}_{\mathrm{F}}(\mathrm{pH}$ tanah yang diukur langsung di lapangan) dengan $\mathrm{pH}$ meter (Ahern et al., 2004), $\mathrm{pH}_{\mathrm{FOX}}$ (pH tanah yang diukur di lapangan setelah dioksidasi dengan hidrogen peroksida 30\%) dengan $\mathrm{pH}$ - meter (Ahern et al., 2004) dan potensial redoks diukur dengan redox-meter sedangkan peubah kualitas tanah yang dianalisis di Laboratorium tanah Balai Riset Perikanan Budidaya Air Payau dan Penyuluhan Perikanan, Maros, Provinsi Sulawesi Selatan dapat dilihat pada Tabel 1.

Pengukuran dan pengambilan contoh air di tambak mengikuti titik pengambilan contoh tanah dilakukan pada jam 09.0016.00. Pengukuran in situ kualitas air meliputi pengukuran suhu, $\mathrm{pH}$, salinitas dan oksigen terlarut menggunakan Hydrolab $^{\circledR}$ Minisonde. Contoh air untuk analisis di laboratorium diambil dengan menggunakan Kmerer Water Sampler dan dipreservasi mengikuti petunjuk APHA (2005). Peubah kualitas air yang dianalisis di Laboratorium air Balai Riset Perikanan Budidaya Air Payau dan Penyuluhan Perikanan (BRPBAP3), Maros dapat dilihat pada Tabel 1.

Produksi total tambak merupakan
produksi total dari udang vaname Litopenaeus vannamei dan ikan bandeng Chanos chanos (Hanafi, 1990; Mustafa dan Ratnawati, 2007), sebab tambak yang terpilih semuanya melakukan budidaya secara polikultur antara udang vaname dan ikan bandeng.

Data produksi tambak diperoleh melalui wawancara dengan mengajukan kuesioner secara terstruktur terhadap responden. Produksi tambak yang dicatat adalah produksi 3 tahun terakhir atau 6 siklus terakhir yang selanjutnya dirata-ratakan. Responden terpilih adalah pengelola dari tambak yang diukur dan diambil contoh tanah dan contoh airnya.

Tabel 1. Peubah kualitas tanah dan air yang dianalisis di laboratorium tanah dan air BRPBAP3, Maros.

\begin{tabular}{lll}
\hline \multicolumn{1}{c}{ Peubah } & \multicolumn{1}{c}{ Metode Analisis/Alat Ukur } & \multicolumn{1}{c}{ Pustaka } \\
\hline Kualitas Tanah: & & \\
$\mathrm{pH}_{\mathrm{H} 2 \mathrm{O}}$ & $\mathrm{pH}$ dari ekstrak H2O (Hanna HI 8424) & Eviati dan Sulaeman \\
$\mathrm{pH}_{\mathrm{KCl}}$ & $\mathrm{pH}$ dari ekstrak KCl (Hanna HI 8424) & Eviati dan Sulaeman \\
$\mathrm{C}$ Organik & Metode Walkley dan Black & Eviati dan Sulaeman \\
\hline
\end{tabular}




\begin{tabular}{lll}
\hline \multicolumn{1}{c}{ Peubah } & \multicolumn{1}{c}{ Metode Analisis/Alat Ukur } & \multicolumn{1}{c}{ Pustaka } \\
\hline Bahan organik & Metode Walkley dan Black & Eviati dan Sulaeman \\
Besi (Fe) & Spektrofotometer (Genesys 10vs) & Menon \\
Aluminium (Al) & Spektrofotometer (Genesys 10vs) & Menon \\
$\mathrm{PO}_{4}$ & Metode Bray & Eviati dan Sulaeman \\
N-Total & Metode Kjedhal & Eviati dan Sulaeman \\
Tekstur & Hidrometer & Agus et al. \\
Kualitas Air: & & \\
TSS & Metode gravimetri & Sutrisyani dan Rohani \\
Turbiditas & Metode Nephelometri (Turbidimeter) & Sutrisyani dan Rohani \\
$\mathrm{NH}_{3}$ & Metode fenat & Sutrisyani dan Rohani \\
$\mathrm{NO}_{2}{ }^{-}$ & Metode kolorimetri & Sutrisyani dan Rohani \\
$\mathrm{NO}_{3}{ }^{-}$ & Metode reduksi cadmium & Sutrisyani dan Rohani \\
$\mathrm{PO}_{4}$ & Metode asam askorbat & Sutrisyani dan Rohani \\
$\mathrm{Fe}$ & Metode penantrolin & Sutrisyani dan Rohani \\
$\mathrm{BOT}$ & Metode basa & Sutrisyani dan Rohani \\
\hline
\end{tabular}

\subsection{Analisis Data}

Analisis data setiap peubah kualitas tanah dan air serta produksi total tambak digunakan statistik deskriptif berupa nilai minimum, maksimum, rata-tata dan standar deviasi. Uji Reliabilitas dan Uji Validitas dilakukan terhadap data yang diperoleh dari kuesioner yaitu produksi total. Analisis jalur diterapkan model mediasi dimana peubah kualitas air (sebagai peubah perantara, peubah tergantung dan peubah endogen) memodifikasi pengaruh peubah kualitas tanah (sebagai peubah bebas dan peubah eksogen) terhadap produksi total tambak (sebagai peubah tergantung dan peubah endogen), model rekursif dimana semua anak panah menuju satu arah, dan model persamaan dua jalur dimana peubah kualitas tanah sebagai peubah bebas dan peubah kualitas air dan produksi total tambak sebagai peubah tergantung.

Mendeteksi adanya gejala multikolinearitas yaitu gejala korelasi antarpeubah kualitas tanah maupun kualitas air tambak ditentukan dengan koefisien korelasi. Persamaan regresinya dihitung menggunakan metode langkah mundur (backward) (Draper dan Smith, 1981). Koefisien korelasi kembali digunakan untuk mengetahui korelasi antarpeubah eksogen terpilih dan antarpeubah perantara terpilih dan gabungan peubah eksogen dan perantara. Uji $\mathrm{R}^{2}$ (koefisien determinasi yang disesuaikan) digunakan untuk mengetahui besarnya peubah eksogen menjelaskan peubah perantara serta gabungan peubah eksogen dan perantara menjelaskan peubah tergantung. Uji $\mathrm{F}$ digunakan untuk menguji adanya hubungan linier antarpeubah eksogen maupun antara peubah eksogen dan perantara. Uji $\mathrm{t}$ digunakan untuk mengetahui besarnya pengaruh peubah eksogen terhadap peubah perantara secara sendiri-sendiri atau parsial serta besarnya pengaruh peubah eksogeno dan perantara terhadap peubah tergantung secara parsial pula. Taraf signifikansi ditetapkan sebesar 0,10. Analisis jalur ini menggunakan bantuan program IBM SPSS Statistics 20.

Besarnya pengaruh peubah lain di luar model ditentukan dengan menghitung koefisien analisis jalur yang menunjukkan error dengan menggunakan persamaan (Widarjono, 2010; Suliyanto, 2011):

$\mathrm{Pe}=\sqrt{1-R^{2}}$

Keterangan : $\mathrm{Pe}=$ koefisien analisis jalur, $\mathrm{R}^{2}=$ koefisien determinasi.

Analisis jalur (path analysis) adalah suatu teknik untuk menganalisis hubungan sebab akibat yang terjadi pada regresi 
berganda apabila peubah bebasnya mempengaruhi peubah tergantung, tidak hanya secara langsung, tetapi juga secara tidak langsung (Rutherford dan Choe, 1993; Everitt dan Dunn, 2001). Analisis jalur digunakan untuk menganalisis pola hubungan antar peubah dengan tujuan untuk mengetahui hubungan langsung maupun tidak langsung seperangkat peubah bebas (eksogen) terhadap peubah terikat (endogen). Manfaat dari model analisis jalur adalah untuk menjelaskan fenomena yang diteliti, memprediksi nilai peubah terikat (Y) berdasarkan nilai peubah bebas $(\mathrm{X})$, faktor determinan yaitu penentuan peubah bebas (X) mana yang berpengaruh dominan terhadap peubah terikat (Y), juga dapat digunakan untuk menelusuri mekanisme (jalur-jalur) pengaruh peubah bebas (X) terhadap peubah terikat (Y), dan pengujian model menggunakan metode trimming (Riduwan dan Kuncoro, 2008).

Penentuan besarnya pengaruh, baik pengaruh langsung, pengaruh tidak langsung dan pengaruh total peubah eksogenous terhadap peubah endogenous dihitung berdasarkan petunjuk Everitt dan Dunn (2001), Supranto (2004) dan Sarwono (2007). Diagram hasil analisis jalur dibuat dengan bantuan program AMOS 16.0.

\section{HASIL DAN PEMBAHASAN}

\subsection{Karakteristik Tanah dan Air serta Produksi Total Tambak}

Produksi total tambak polikultur udang vaname dan ikan bandeng di Kabupaten Lamongan berkisar 500-2.600 $\mathrm{kg} / \mathrm{ha} /$ siklus dengan nilai rata-rata $1.318,125$ $\mathrm{kg} / \mathrm{ha} /$ siklus (Tabel 2). Produksi ini merupakan hasil polikultur udang vaname dan ikan bandeng yang umumnya dilakukan di tambak salinitas rendah (tambak sawah) pada priode bulan Nopember-Pebruari (siklus I) dan pada priode bulan Maret-Juni (siklus II) sedangkan pada musim kemarau digunakan untuk kegiatan budidaya sawah. Teknologi yang digunakan adalah mulai dari tradisional plus hingga semi intensif dengan padat penebaran udang vaname 50.000-225.000 ekor/ha dan ikan bandeng 1.000-15.000 ekor/ha. Pembudidaya tambak di Kabupaten Lamongan menerapkan budidaya sistem polikultur dengan harapan dapat memperoleh produksi yang lebih tinggi dibanding sistem budidaya monokultur dengan pertimbangan efisiensi lahan yang digunakan. Sistem polikultur adalah budidaya bersama dari berbagai spesies ikan dengan tingkat tropik yang sama, organisme tersebut secara bersamasama melakukan proses biologi dan kimia dengan beberapa keuntungan yang bersinergi dalam ekosistem. Udang vaname dan ikan bandeng adalah komoditas yang dapat dipolikulturkan di tambak karena kedua komoditas tersebut secara umum menuntut kondisi lingkungan yang relatif sama, tetapi menempati relung ekologi yang berbeda dalam tambak. Perbedaan habitat, makanan dan sifat non predator dari kedua komoditas tersebut yang menyebabkan tidak terjadi kompetisi di antaranya. Polikultur ini memiliki keunggulan antara lain meminimalkan resiko penyakit udang (mengurangi resiko kegagalan panen), meniadakan penggunaan antibiotik, meminimalkan biaya operasional, memperbaiki pertumbuhan udang dan ikan, menghasilkan produk makanan laut berkualitas dan dapat memberikan nilai tambah bagi petani (Mangampa dan Hendradjat, 2014). Udang vaname merupakan komoditas perikanan yang mempunyai prospek untuk dikembangkan karena dapat dibudidayakan secara polikulur dengan beberapa komoditas. Pada polikultur udang vaname dengan bandeng dengan rasio kepadatan udang vaname dan bandeng 80.000:500 ekor/ha, menghasilkan indeks kompetisi negatif untuk kedua komoditas (Mansyur, 2007).

$\mathrm{pH}_{\mathrm{F}}$ atau $\mathrm{pH}$ fresh adalah $\mathrm{pH}$ tanah yang diukur langsung di lapangan dengan $\mathrm{pH}$-meter sedangkan $\mathrm{pH}_{\mathrm{FOX}}$ adalah $\mathrm{pH}$ tanah yang diukur di lapangan dengan $\mathrm{pH}$-meter setelah dioksidasi dengan hidrogen peroksida 30\% (Ahern et al., 2004). Selisih nilai $\mathrm{pH}_{\mathrm{F}}$ 
dan $\mathrm{pH}_{\mathrm{FOX}}$ digunakan untuk menentukan potensi kemasaman tanah. Semakin besar nilai selisihnya, semakin tinggi nilai potensi kemasamannya. $\mathrm{pH}_{\mathrm{F}}$ dan $\mathrm{pH}_{\mathrm{FOX}}$ tanah tambak polikultur udang vaname dan ikan bandeng di Kabupaten Lamongan rata-rata 6,693 dan 7,310. Nilai $\mathrm{pH}_{\mathrm{F}}-\mathrm{pH}_{\mathrm{FOX}}$ yang rendah ini menunjukkan bahwa tanah tambak di Kabupaten Lamongan tidak memiliki potensi kemasaman yang tinggi sebab lahannya berasal dari hasil konversi lahan sawah dan sebagian dari lahan rawa yang memiliki jenis tanah aluvial non sulfat masam. Kawasan tambak yang memiliki tanah sulfat masam, selisih nilai pHF dan pHFOX dapat mencapai $>5$.

Redoks (Eh) merupakan gambaran proses reaksi reduksi dan oksidasi yang terjadi di dalam tanah sehingga parameter redoks ini menjadi bagian dari parameter yang mengindikasikan kualitas tanah tambak (Nana dan Putra, 2008). Nilai Eh atau pe yang tinggi dan positif menunjukkan kondisi oksidatif, sebaliknya nilai Eh atau pe yang rendah bahkan negatif menunjukkan kondisi reduktif. Potensial redoks mempengaruhi status $\mathrm{N}$ dalam tanah, ketersediaan $\mathrm{P}$ dan $\mathrm{Si}$, kadar $\mathrm{Fe}^{2+}, \mathrm{Mn}^{2+}$, dan $\mathrm{SO}_{4}{ }^{2-}$ secara langsung dan kadar $\mathrm{Ca}^{2+}, \mathrm{Mg}^{2+}, \mathrm{Cu}^{2+}, \mathrm{Zn}^{2+}$ dan $\mathrm{MoO}_{4}{ }^{2-}$ secara tidak langsung dan dekomposisi bahan organik serta $\mathrm{H}_{2} \mathrm{~S}$ (Ponnamperuma, 1978). Rata-rata potensial redoks tanah tambak polikultur udang vaname dan ikan bandeng di Kabupaten Lamongan yaitu $-30,125 \mathrm{mV}$ yang berada antara 00-(-100), sehingga menurut Liu (1985) nilai ini dimasukkan dalam status reduksi sedang dimana pada kondisi ini senyawa organik direduksi. Eh akan berstatus oksidatif jika bernilai $>400$ $\mathrm{mV}$, sedangkan status reduksi rendah terjadi pada tanah dengan nilai Eh antara 400-200 $\mathrm{mV}$, status reduksi sedang berkisar antara 00(-100) $\mathrm{mV}$ dan status reduksi terjadi pada tanah yang bernilai $\mathrm{Eh}<(-100) \mathrm{mV}$.

Rata-rata $\mathrm{C}$ organik tanah di tambak polikultur udang vaname dan ikan bandeng di Kabupaten Lamongan adalah 1,016\%, diklasifikasikan sebagai tanah mineral yang mempunyai kandungan bahan organik sedang dan baik untuk lokasi budidaya (Boyd et al., 2002) dan berkaitan dengan produktivitas tanah berdasarkan kandungan $\mathrm{C}$ organik, dikategorikan mengandung bahan organik sedang dan merupakan tanah produktif (Adhikari, 2003). Menurut Boyd (2008), kandungan karbon organik lebih dari 2,5\% sudah termasuk berlebihan dan ada kecenderungan akan terbentuk zona anaerobik di dasar tambak. Nilai kandungan karbon organik sebesar 2,5\% termasuk optimum untuk tambak yang dipupuk dan cukup sesuai untuk tambak yang diberi pakan. Bahan organik yang tinggi pada suatu tambak berpotensi menyebabkan terbentuknya senyawa metan dan hidrogen sulfida. Kedua senyawa tersebut dapat mematikan organisme yang dibudidayakan.

Bahan organik umumnya berasal dari endapan karbohidrat, protein dan sel-sel lainnya baik yang mudah (karbohidrat dan protein sederhana) atau yang sulit (karbohidrat dan protein kompleks) didegradasi oleh mikroorganisme yang biasanya berasal dari sisa makanan, pupuk dan organisme mati (Boyd, 1995). Kandungan bahan organik tanah di tambak polikultur udang vaname dan ikan bandeng di Kabupaten Lamongan rata-rata $1,751 \%$, termasuk baik dan tidak tergolong sebagai tanah organosol atau tanah gambut. Bahan organik tanah yang baik untuk tambak berkisar 1,7\%-5,2\% (Boyd et al., 2002). Mintardjo et al. (1985), telah memberikan angka-angka yang dapat digunakan untuk menentukan secara kuantitatif kandungan bahan organik di dalam tanah, yaitu kandungan bahan organik kurang dari $1,5 \%$ tingkat kesuburannya rendah, kandungan bahan organik 1,6-3,5\% tingkat kesuburannya sedang dan kandungan bahan organik lebih dari 3,6\% tingkat kesuburannya tinggi. Tanah gambut adalah tanah yang dicirikan dengan kandungan bahan organik yang melebihi 26\% (Boyd et al., 2002).

Kandungan unsur $\mathrm{Fe}$ dalam tanah rata-rata $115,875 \mathrm{mg} / \mathrm{L}$ termasuk rendah karena tanah tambak polikultur udang 
vaname dan ikan bandeng di Kabupaten Lamongan memiliki jenis tanah aluvial non sulfat masam. Tambak tanah sulfat masam di Tarakan, Kalimantan Timur Kandungan Fe tergolong tinggi yang mencapai kisaran 5.265-5.670 mg/L (rata-rata: $5.482 \mathrm{mg} / \mathrm{L}$ ) pada awal karakterisasi dan menurun pada tambak yang direklamasi mencapai 4.260$5.315 \mathrm{mg} / \mathrm{L}$ (rata-rata: $4.955 \mathrm{mg} / \mathrm{L}$ ) dan yang tidak direklamasi cenderung meningkat yaitu mencapai 5.390-5.675 mg/L (rata-rata: 5.539 mg/L) (Pantjara et al., 2010). Di tambak tanah sulfat masam yang dicirikan dengan kandungan $\mathrm{Fe}$ dan $\mathrm{Al}$ yang tinggi dapat mencapai 4.955,7 dan 636,0 $\mathrm{mg} / \mathrm{L}$ di Kabupaten Luwu, Provinsi Sulawesi Selatan (Mustafa dan Sammut, 2010).

Kandungan $\mathrm{PO}_{4}$ yang mencapai ratarata $113,754 \mathrm{mg} / \mathrm{L}$ dan Kandungan $\mathrm{N}$ total rata-rata $0,181 \%$ di tanah tambak polikultur udang vaname dan ikan bandeng di Kabupaten Lamongan tergolong baik. Ketersediaan fosfat $\left(\mathrm{PO}_{4}\right)>60 \mathrm{mg} / \mathrm{L}$ dalam tanah tambak dapat digolongkan sebagai slight atau tergolong baik dengan faktor pembatas yang sangat mudah diatasi (Karthik et al., 2005). Selanjutnya dijelaskan bahwa kandungan N total tanah tambak yang lebih besar dari $0,05 \%$ tergolong baik untuk budidaya tambak.

Tekstur adalah salah satu sifat fisik tanah yang memberikan gambaran tentang ukuran partikel penyusun tubuh tanah yang dominan yang dinyatakan dalam per- bandingan relatif antara proporsi ukuran dari fraksi atau partikel penyusun fase padat tanah dengan berat tanah yang dinyatakan dalam kelas tekstur tanah (Subroto, 2003). Tekstur tanah sangat penting untuk diketahui karena dapat memberikan informasi yang berhubungan dengan tingkat stabilitas tanah, tingkat pergerakan air tanah, tingkat difusi gas ke udara atau sebaliknya, tingkat aktivitas mikroorganisme dan flora fauna tanah, serta jumlah bahan organik (Hanafiah, 2005). Hasil analisis tekstur tanah yang terdiri dari fraksi pasir $42,50 \%$, liat $29,00 \%$ dan debu 28,50\%, menunjukkan bahwa substrat di tambak polikultur udang vaname dan ikan bandeng di Kabupaten Lamongan adalah lempung berpasir. Tekstur lempung berpasir adalah tanah yang bertekstur sedang tetapi agak kasar. Tanah bertekstur lempung akan mempunyai partikel-partikel yang mempunyai rasa ketiganya secara proporsional, apabila yang terasa lebih dominan adalah sifat pasir, maka berarti tanah bertekstur lempung berpasir (Hanafiah, 2005). Jenis tanah yang baik untuk usaha pertambakan adalah lempung berpasir (clay loam), liat berpasir (sandy clay), liat berlumpur (silty clay) dan liat (clay). Jenis tanah lempung berpasir sangat sesuai untuk pertumbuhan makanan alami, sedangkan jenis tanah pasir dan pasir berlumpur bersifat sangat porous, sehingga tidak dapat menahan air serta miskin hara (Hidayanto et al., 2004).

Tabel 2. Statistik deskriptif produksi total, kualitas tanah, dan kualitas air di tambak polikultur udang vaname dan ikan bandeng di Kabupaten Lamongan.

\begin{tabular}{lcccc}
\hline \multicolumn{1}{c}{ Faktor/Peubah } & Minimum & Maksimum & Rata-rata & $\begin{array}{c}\text { Standar } \\
\text { Deviasi }\end{array}$ \\
\hline $\begin{array}{l}\text { Produksi: } \\
\text { Panen Total (Vaname+Bandeng) } \\
\text { (Kg/ha/siklus) }\end{array}$ & 500 & 2.600 & $1.318,125$ & 766,289 \\
Kualitas Tanah: & & & & \\
pHF & 6,50 & 6,99 & 6,693 & 0,146 \\
pHFOX & 6,75 & 7,74 & 7,310 & 0,382 \\
Potensial Redox (mV) & $-87,00$ & 43,00 & $-30,125$ & 40,484 \\
pH & 7,66 & 8,13 & 7,979 & 0,176 \\
\hline
\end{tabular}




\begin{tabular}{|c|c|c|c|c|}
\hline Faktor/Peubah & Minimum & Maksimum & Rata-rata & $\begin{array}{l}\text { Standar } \\
\text { Deviasi }\end{array}$ \\
\hline $\mathrm{pH}$ & 6,72 & 7,06 & 6,918 & 0,120 \\
\hline C,Organik (\%) & 0,09 & 1,81 & 1,016 & 0,614 \\
\hline Bahan organik (\%) & 0,16 & 3,12 & 1,751 & 1,058 \\
\hline $\mathrm{Fe}(\mathrm{mg} / \mathrm{L})$ & 9,50 & 395,50 & 115,875 & 120,163 \\
\hline $\mathrm{Al}(\mathrm{mg} / \mathrm{L})$ & 1,00 & 171,00 & 56,688 & 66,919 \\
\hline $\mathrm{PO}_{4}(\mathrm{mg} / \mathrm{L})$ & 10,89 & 200,08 & 113,754 & 59,276 \\
\hline $\mathrm{P}_{2} \mathrm{O}_{5}(\mathrm{mg} / \mathrm{L})$ & 8,14 & 149,54 & 85,016 & 44,301 \\
\hline N-Total $(\%)$ & 0,06 & 0,35 & 0,181 & 0,098 \\
\hline Pasir $(\%)$ & 38,00 & 46,00 & 42,50 & 3,162 \\
\hline Liat (\%) & 0,00 & 44,00 & 29,00 & 18,205 \\
\hline Debu $(\%)$ & 16,00 & 54,00 & 28,50 & 15,919 \\
\hline \multicolumn{5}{|l|}{ Kualitas Air: } \\
\hline Suhu $\left({ }^{\circ} \mathrm{C}\right)$ & 29,03 & 34,77 & 31,963 & 1,712 \\
\hline $\mathrm{DO}(\mathrm{mg} / \mathrm{L})$ & 6,01 & 19,50 & 10,744 & 4,767 \\
\hline Salinitas (ppt) & 0,12 & 0,38 & 0,250 & 0,088 \\
\hline $\mathrm{pH}$ & 8,69 & 10,49 & 9,433 & 0,624 \\
\hline $\mathrm{TSS}(\mathrm{mg} / \mathrm{L})$ & 29,00 & 155,00 & 79,375 & 46,797 \\
\hline Turbiditas (NTU) & 191,00 & 850,00 & 499,750 & 252,044 \\
\hline $\mathrm{NH}_{3}(\mathrm{mg} / \mathrm{L})$ & 0.08 & 4.39 & 1.574 & 1.637 \\
\hline $\mathrm{NO}_{2}^{-}(\mathrm{mg} / \mathrm{L})$ & 0,02 & 0,09 & 0,044 & 0,021 \\
\hline $\mathrm{NO}_{3}{ }^{-}(\mathrm{mg} / \mathrm{L})$ & 0,17 & 2,30 & 0,724 & 0,786 \\
\hline $\mathrm{PO}_{4}(\mathrm{mg} / \mathrm{L})$ & 0,02 & 1,05 & 0,311 & 0,374 \\
\hline BOT (mg/L) & 3,29 & 24,82 & 11,098 & 6,881 \\
\hline
\end{tabular}

Suhu air dapat mempengaruhi kelangsungan hidup, pertumbuhan, morfologi, reproduksi, tingkah laku, pergantian kulit dan metabolisme udang. Disamping itu suhu juga berpengaruh terhadap kelarutan gas-gas, kecepatan reaksi unsur dan senyawa yang terkandung dalam air. Suhu air di tambak polikultur udang vaname dan ikan bandeng di Kabupaten Lamongan berkisar antara 29,03 sampai $34,77^{\circ} \mathrm{C}$ dengan rata-rata $31,963^{\circ} \mathrm{C}$. Suhu air yang tinggi terukur pada siang hari di tambak dengan air yang sangat dangkal. Udang vaname hidup pada toleransi suhu $16-36^{\circ} \mathrm{C}$ dan optimal pada suhu 28 $30^{\circ} \mathrm{C}$ (Anonim 2003). Kisaran suhu air yang baik bagi kehidupan udang vaname adalah antara $26-30^{\circ} \mathrm{C}$, sedangkan suhu air yang baik untuk ikan bandeng adalah $27-30^{\circ} \mathrm{C}$ (Ismail et al., 1993).
Salinitas air tambak berkisar dari 0,12 sampai 0,38 ppt dengan rata-rata $0,250 \mathrm{ppt}$, tergolong rendah karena tambak polikultur udang vaname dan ikan bandeng di Kabupaten Lamongan berjarak cukup jauh (20-40 km) dari laut sebagai sumber air asin dan dulunya merupakan lahan sawah yang dikonversi menjadi tambak sawah (tambak salinitas rendah). Selain itu juga sebagai akibat dari pengukuran yang dilakukan pada saat musim hujan yang dapat menyebabkan tingginya pengenceran yang dapat menurunkan salinitas. Walaupun nilai salinitas ini tergolong rendah namun tidak memberikan pengaruh yang nyata terhadap produksi total tambak karena udang vaname dan ikan bandeng merupakan organisme eurihalin. Udang vaname dapat menoleransi salinitas 1-50 ppt (Anonim, 2003). Kisaran salinitas optimal untuk udang vaname berkisar 15-30 
ppt (Haliman dan Adijaya, 2005). Ikan bandeng bersifat eurihalin yaitu tahan terhadap perubahan salinitas yang besar, sehingga ikan bandeng dapat hidup di air payau (salinitas 10-25 ppt) dan bahkan juga di air tawar (Mudjiman, 1986). Selain itu ikan bandeng mudah beradaptasi dan bertoleransi tinggi terhadap salinitas (0-60 ppt) (Arsyad dan Sanusi, 1990). Menurut Blanco (1970), bandeng masih dapat tumbuh baik pada salinitas 0-50 ppt di Filipina. Di berbagai daerah di Indonesia telah berkembang budidaya udang dan ikan bandeng pada lahan tambak bersalinitas rendah (lebih kecil dari 10 ppt) untuk mencegah terjangkitnya penyakit penyebab kematian udang (Sudradjat dan Wedjatmiko, 2010).

Total suspendid solid (TSS) atau total zat padat tersuspensi adalah residu-residu dari semua zat padat (pasir, lumpur dan tanah liat) atau partikel-partikel yang tersuspensi dalam air dan dapat berupa komponen hidup (biotic) seperti fitoplankton, zooplankton, bakteri, fungi ataupun komponen mati (abiotik) seperti detritus dan partikel-partikel anorganik (Tarigan dan Edward, 2003). Rata-rata kandungan TSS yang terukur di tambak polikultur udang vaname dan ikan bandeng di Kabupaten Lamongan adalah $79,375 \mathrm{mg} / \mathrm{L}$ masih layak bagi kehidupan udang vaname dan ikan bandeng dan masih sesuai dengan nilai ambang batas yang ditetapkan oleh Kementerian KLH (1988) untuk kepentingan perikanan pada biota laut yaitu $<80 \mathrm{mg} / \mathrm{L}$. Selanjutnya dijelaskan bahwa TSS perairan yang baik untuk usaha budidaya perikanan laut adalah $5-25 \mathrm{mg} / \mathrm{L}$.

Turbiditas (kekeruhan) menggambarkan sifat optik air yang ditentukan berdasarkan banyaknya cahaya yang diserap dan dipancarkan oleh bahan-bahan yang terdapat di dalam air. Kekeruhan disebabkan oleh adanya bahan organik dan anorganik yang tersuspensi dan terlarut (misalnya lumpur, dan pasir halus), maupun bahan anorganik dan organik yang berupa plankton dan mikroorganisme lain (Davis dan Cornwel, 1991). Turbiditas yang terukur antara
191,00-850,00 NTU dengan rata-rata 499,750 NTU tergolong tinggi. Tingginya turbiditas di tambak polikultur udang vaname dan ikan bandeng di Kabupaten Lamongan sebagai akibat dari pengukuran yang dilakukan pada saat musim hujan. Hujan yang sering terjadi menyebabkan lumpur yang terdapat pada pematang larut ke dalam tambak sehingga meningkatkan kekeruhan. Menurut Cech (2010), turbiditas lebih besar 50 NTU sudah tergolong tinggi dan turbiditas lebih besar 25 NTU sudah dapat mengganggu organisme akuatik.

Hasil pengukuran kadar amonia $\left(\mathrm{NH}_{3}\right)$ berkisar 0.08-4.39 mg/L dengan ratarata $1.574 \mathrm{mg} / \mathrm{L}$, relatif tinggi untuk tambak polikultur udang vaname dan ikan bandeng. Tingginya kandungan amonia akibat limbah pupuk pertanian (urea) dan limbah domestik karena sebagian besar tambak merupakan bekas lahan sawah yang letaknya berbatasan dengan sawah dan pemukiman. Sumber kandungan amonia di perairan berasal dari hasil pemecahan nitrogen organik (urea) dan reduksi gas nitrogen yang berasal dari limbah domestik. Batas kelayakan kandungan amonia untuk budidaya tambak udang 0,25 $\mathrm{mg} / \mathrm{L}$ dengan optimumnya $0 \mathrm{mg} / \mathrm{L}$ (Poernomo, 1992). Kadar amoniak yang baik untuk pertumbuhan udang vaname adalah 0,1 $\mathrm{mg} / \mathrm{L}$ (Anonim, 2003). Total amonia yang baik bagi kehidupan udang dewasa adalah kurang dari $3 \mathrm{mg} / \mathrm{L}$ dan bagi kehidupan benur kurang dari $1 \mathrm{mg} / \mathrm{L}$. Bila proses pembusukan tidak berlangsung lancar, maka terjadi penumpukan sampai konsentrasi yang membahayakan udang (Buwono, 1993).

Nitrit $\left(\mathrm{NO}_{2}^{-}\right)$dan nitrat $\left(\mathrm{NO}_{3}{ }^{-}\right)$ada di dalam air sebagai hasil dari oksidasi. Nitrit merupakan hasil oksidasi dari amonia dengan bantuan bakteri Nitrosomonas dan nitrat hasil dari oksidasi nitrit dengan bantuan bakteri Nitrobacter. Keduanya selalu ada dalam konsentrasi yang rendah karena tidak stabil akibat proses oksidasi dan sangat tergantung pada keberadaan bahan yang dioksidasi dan bakteri. Kedua bakteri tersebut akan optimal melakukan proses nitrifikasi pada $\mathrm{pH}$ 7,0-7,3 
(Malone dan Burden, 1988). Untuk peubah nitrit didapatkan kisaran 0,02-0,09 $\mathrm{mg} / \mathrm{L}$ dengan rata-rata $0,044 \mathrm{mg} / \mathrm{L}$, nilai ini optimal untuk tambak. Kisaran optimal nitrit untuk budidaya vaname yakni $0,01-0,05 \mathrm{mg} / \mathrm{L}$ (Adiwijaya et al., 2003). Menurut Suprapto (2005), kandungan nitrit yang dapat ditoleransi oleh udang vaname berkisar $0,1-1$ $\mathrm{mg} / \mathrm{L}$. Kandungan nitrit direferensikan $<0.1$ mg/L (Haliman dan Adijaya, 2005). Nitrit merupakan bentuk nitrogen yang tidak disukai setelah amoniak dalam sistem budidaya perairan. Perairan yang tercemar biasanya mengandung nitrit hingga $2 \mathrm{mg} / \mathrm{L}$, selain itu kadar nitrit antara 0,5-5 mg/L membahayakan kehidupan organisme (Stickney, 1979). Sementara peubah nitrat yang berkisar 0,17-2,30 mg/L dengan ratarata $0,724 \mathrm{mg} / \mathrm{L}$ menunjukkan nilai yang termasuk kategori normal karena kandungan nitrat yang dibutuhkan untuk pertumbuhan alga di perairan adalah $0,2-0,9 \mathrm{mg} / \mathrm{L}$ dan optimal pada kisaran $0,1-4,5 \mathrm{mg} / \mathrm{L}$. Nitrat merupakan salah satu bentuk $\mathrm{N}$ yang dapat dimanfaatkan secara langsung oleh tanaman akuatik selain $\mathrm{NH}_{4}$ dan $\mathrm{N}_{2}^{-}$. Nitrat adalah bentuk utama $\mathrm{N}$ di perairan alami dan merupakan nutrien yang penting untuk budidaya tambak sebab $\mathrm{NO}_{3}^{-}$inilah yang dimanfaatkan tanaman dan alga akuatik (Mustafa dan Athirah, 2014). Clifford (1994) mengemukakan bahwa konsentrasi nitrat yang optimal untuk udang vaname berkisar $0,4-0,8 \mathrm{mg} / \mathrm{L}$.

Fosfat $\left(\mathrm{PO}_{4}\right)$ merupakan nutrien utama selain nitrat yang diperlukan untuk pertumbuhan fitoplankton dalam perairan, selain itu fosfat esensial untuk pernafasan, produksi protein, pembelahan sel dan pertumbuhan. Keberadaan unsur ini seringkali mempengaruhi kesuburan perairan (Ranoemihardjo et al., 1985). Rata-rata kandungan fosfat menunjukkan nilai $0,311 \mathrm{mg} / \mathrm{L}$, sedikit di atas nilai optimal. Tingginya kandungan fosfat karena tambak berbatasan dengan persawahan dan pemukiman, diduga limbah pupuk pertanian dan limbah domestik terikut masuk ke dalam tambak melalui saluran. Kisaran optimal kandungan fosfat pada perairan berkisar 0,101-0,211 mg/L. Apabila kandungan fosfat cukup besar melebihi kebutuhan normal organisme nabati, maka perairan akan terlalu subur (eutrofikasi) dan apabila keadaan ini ditunjang pula adanya unsur hara lain akan merangsang pertumbuhan plankton secara melimpah (Wardoyo, 1982). Konsentrasi total fosfor maksimal untuk lingkungan tambak sebesar 1,20 mg/L (Boyd, 1990).

Hasil pengukuran konsentrasi bahan organik total (BOT) berkisar 3,29-24,82 $\mathrm{mg} / \mathrm{L}$ dengan rata-rata $11,098 \mathrm{mg} / \mathrm{L}$ yang tergolong layak untuk budidaya tambak. Kandungan bahan organik terlarut suatu perairan normal adalah maksimum $15 \mathrm{mg} / \mathrm{L}$, apabila kandungan bahan organik terlarut tinggi maka dapat menurunkan kandungan oksigen terlarut dalam air (Boyd, 1990), disebabkan oleh proses dekomposisi bahan organik yang membutuhkan oksigen terlarut. Konsentrasi bahan organik yang layak untuk kegiatan budidaya udang vaname adalah $<55$ mg/L (Adiwijaya et al., 2003).

\subsection{Hubungan Produksi Total dan Lingkungan Tambak}

Analisis jalur, peubah kualitas tanah merupakan peubah bebas dan peubah eksogen, dari 15 peubah kualitas tanah (Tabel 2) yang dianalisis ternyata hanya 2 peubah yang mempengaruhi produksi total polikultur udang vaname dan ikan bandeng di tambak Kabupaten Lamongan yaitu $\mathrm{pH}_{\mathrm{KCL}}$ dan Aluminium (Al) (Gambar 1). $\mathrm{pH}_{\mathrm{KCL}}$ hanya berpengaruh nyata dengan pengaruh langsung (direct effect) sebesar 0,314 $(P<0,10)$ terhadap produksi total (produksi meningkat karena pengaruh $\mathrm{pH}_{\mathrm{KCL}}$ sebesar $31,4 \%$ ), sedangkan Al berpengaruh sangat nyata dengan pengaruh langsung sebesar $0,426 \quad(P<0,01)$ terhadap produksi total (produksi menurun karena pengaruh Al sebesar 42,6\%). Dari 11 peubah kualitas air yang merupakan peubah perantara, tergantung dan endogen dalam penelitian ini, ternyata hanya 2 peubah yang mem- 
pengaruhi produksi total tambak polikultur udang vaname dan ikan bandeng di Kabupaten Lamongan yaitu: oksigen terlarut (DO) dan $\mathrm{pH}$ air (Gambar 1). DO berpengaruh nyata $(P<0,10)$ dengan pengaruh langsung sebesar $-0,367$ terhadap produksi total (produksi menurun karena pengaruh DO sebesar 36,7\%) dan $\mathrm{pH}$ air berpengaruh nyata $(P<0,10)$ dengan pengaruh langsung sebesar $-0,245$ terhadap produksi total (produksi menurun karena pengaruh $\mathrm{pH}$ air sebesar 24,5\%). Pengaruh langsung, tidak langsung dan total antar peubah secara lengkap tersaji pada Tabel 3.

$\mathrm{pH}_{\mathrm{KCL}}$ tanah tambak polikultur udang vaname dan ikan bandeng di Kabupaten Lamongan rata-rata 6,91 relatif rendah (mendekati netral). Peningkatan $\mathrm{pH}_{\mathrm{KCL}}$ tanah dapat menurunkan kelarutan $\mathrm{Al}$ sehingga kondisi tanah tambak dapat lebih baik yang dapat berdampak pada peningkatan produksi total tambak. Kelarutan aluminium sangat dipengaruhi oleh $\mathrm{pH}$ tanah. Dalam keadaan sangat masam $(\mathrm{pH}<3,5)$ banyak aluminium menjadi larut dan dijumpai dalam bentuk kation $\left(\mathrm{Al}_{3}+\right)$ dan hidroksi Al. Bentuk $\mathrm{Al}_{3}+$ merupakan bentuk aluminium yang paling dominan pada $\mathrm{pH}<4.0$, sedangkan bentuk $\mathrm{Al}(\mathrm{OH}) 2+$ mulai terbentuk pada $\mathrm{pH}$ antara 4,0-5,0 dan pada $\mathrm{pH}>5,5$ pengaruh $\mathrm{Al}$ bentuk $\mathrm{Al}_{3}+$ sudah dapat diabaikan. Aluminium, ketika ada dalam konsentrasi tinggi, bersifat racun bagi hewan yang bernafas dengan insang (Handayanto dan Hairiah, 2007). Peningkatan konsentrasi logam (misal aluminium, seng dan mangan) sering berkaitan dengan $\mathrm{pH}$ rendah di danau dan sungai. Hubungan terbalik antara konsentrasi aluminium dan $\mathrm{pH}$ telah diidentifikasi di perairan tawar dan pesisir. Konsentrasi aluminium anorganik 0 sampai $0,6 \mathrm{mg} /$ liter telah diukur di danau-danau di New York dan sungai-sungai dengan $\mathrm{pH}$ berkisar dari 7,2 sampai 4,2 (Anonim, 2012).

Kandungan Al tanah tambak di Kabupaten Lamongan cukup tinggi yaitu berkisar dari 1,00 sampai $171,00 \mathrm{mg} / \mathrm{L}$ dengan rata-rata 56,688 mg/L. Kandungan $\mathrm{Al}$ yang tinggi ditemukan pada tambak yang sumber airnya menggunakan air tanah bor yang terikut air tanah keluar pada saat dipompa. Kandungan $\mathrm{Al}$ tanah yang tinggi berpengaruh langsung terhadap produksi total di mana peningkatan kandungan $\mathrm{Al}$ tanah berdampak pada penurunan produksi total tambak. Aluminium ketika ada dalam konsentrasi tinggi telah lama diketahui bersifat racun bagi hewan yang bernafas dengan insang. Aluminium menyebabkan kehilangan ion-ion dalam plasma dan limfa darah sehinggga mengakibatkan kegagalan osmoregulasi. Aluminium yang berbentuk monomerik anorganik (labil) dapat menurunkan aktivitas enzim-enzim insang yang berperanan penting dalam penyerapan aktif ion pada ikan. Peningkatan konsentrasi aluminium juga dapat menurunkan kadar fosfor terlarut yang diperlukan organisme air dengan cara membentuk ikatan kompleks $\mathrm{AlPO}_{4}$ anorganik yang mempolimerisasi dan menyerap fosfor terlarut maupun fosfor partikel, sehingga menyebabkannya menggumpal dan mengendap (Anonim, 2012). Upaya yang dapat dilakukan untuk mengantisipasi kandungan $\mathrm{Al}$ pada tanah adalah dengan perbaikan tanah dasar tambak (reklamasi) dapat dilakukan dengan jalan penjemuran tanah dasar, perendaman dan pencucian tambak. Penjemuran dan perendaman senyawa Al akan larut dalam air, kemudian pencucian dilakukan untuk menghilangkan konsentrasi Al yang masih mengendap di dasar tambak. Tahap akhir yang dilakukan adalah meningkatkan $\mathrm{pH}$ tanah melalui pengapuran. Menurut Swastika (2001), kapur mengandung senyawa Ca yang mampu menetralkan pengaruh buruk dari $\mathrm{Al}$ dan pengaruh kurang menguntungkan dari kemasaman tanah. Naiknya nilai $\mathrm{pH}$ tanah, maka unsur-unsur hara seperti $\mathrm{P}$ akan mudah diserap dan tidak diikat oleh $\mathrm{Fe}$ maupun $\mathrm{Al}$ (Hardjowigeno, 2002). Lebih lanjut Mustafa et al. (2008) menyatakan bahwa pengaruh peningkatan kandungan $\mathrm{Fe}, \mathrm{Al}$ dan $\mathrm{SO}_{4}$ dapat berdampak pada penurunan produksi udang vaname. Demikian pula halnya dengan 
produksi budidaya polikultur udang vaname dan ikan bandeng di tambak.

Oksigen terlarut merupakan faktor pembatas di tambak. Oksigen dibutuhkan udang dan ikan untuk respirasi dan proses fisiologi. Namun demikian, oksigen terlarut di tambak polikultur udang vaname dan ikan bandeng di Kabupaten Lamongan dengan konsentrasi rata-rata $10,744 \mathrm{mg} / \mathrm{L}$ ini tergolong tinggi sehingga peningkatan oksigen terlarut pada air tambak dapat menurunkan produksi total tambak. Kadar oksigen terlarut yang baik untuk udang vaname berkisar 4-6 ppm (Haliman dan Adijaya, 2005). Ikan bandeng tumbuh dengan baik pada kisaran oksigen terlarut 3-8 $\mathrm{mg} / \mathrm{L}$ (Ismail et al., 1993). Konsentrasi oksigen terlarut yang tinggi dapat mempengaruhi kesehatan ikan, yaitu akan menimbulkan penyakit yang disebabkan oleh gelembung gas (gas bubble diseases) juga mempengaruhi fungsi fisiologis dan lambatnya pertumbuhan ikan, bahkan dapat menyebabkan kematian (Taufiqull, 2016). Tingginya konsentrasi oksigen terlarut di tambak polikultur udang vaname dan ikan bandeng di Kabupaten Lamongan disebabkan karena pengukuran oksigen terlarut dilakukan pada siang hari (kondisi cuaca cerah) dimana telah terjadi proses fotosintesis yang dapat meningkatkan kelarutan oksigen dalam tambak. Disamping itu teknologi budidaya yang diaplikasikan di tambak polikultur udang vaname dan ikan bandeng di Kabupaten Lamongan adalah teknologi tradisional plus hingga semi intensif (padat penebaran lebih tinggi dari teknologi tradisional) sehingga tambak membutuhkan pasokan oksigen yang lebih tinggi melalui penggunaan kincir air (terutama pada malam hari) selain dari proses difusi dengan udara, sirkulasi air oleh angin dan fotosintesis yang dilakukan oleh fitoplankton. Penerapan penggunaan kincir air pada tambak budidaya udang bertujuan untuk aerasi yakni terjadinya percikan air (splashing) dan gelembung udara (bubling) yang dapat menambah oksigen terlarut (Boyd, 2003).

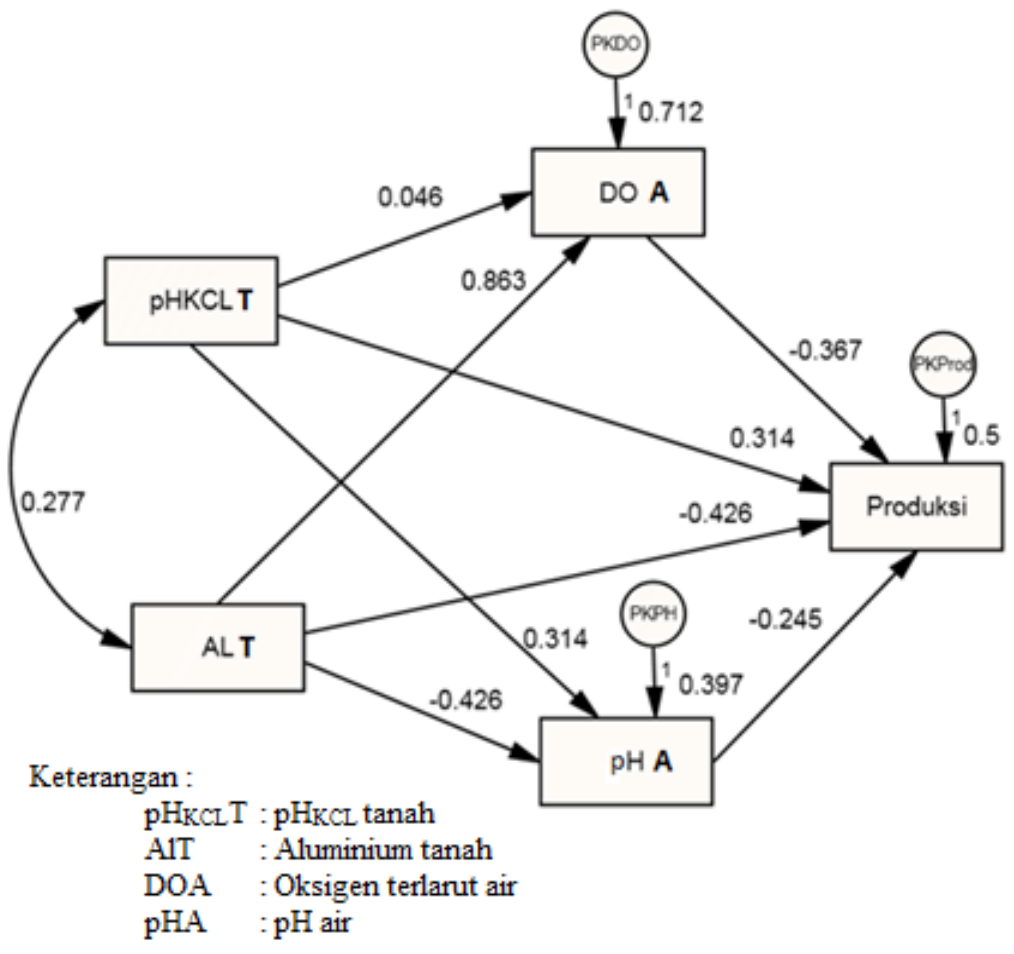

Gambar 1. Diagram hasil analisis jalur kualitas tanah terhadap kualitas air dan produksi total pada tambak polikultur udang vaname dan ikan bandeng di Kabupaten Lamongan, Provinsi Jawa Timur. 
Tabel 3. Nilai pengaruh langsung, tidak langsung dan total setiap korelasi dalam analisis jalur untuk faktor lingkungan dan produksi total pada tambak polikultur udang vaname dan ikan bandeng di Kabupaten Lamongan, Provinsi Jawa Timur.

\begin{tabular}{lccc}
\hline Korelasi dalam Analisis & $\begin{array}{c}\text { Pengaruh } \\
\text { Jalur }\end{array}$ & $\begin{array}{c}\text { Pengaruh Tidak } \\
\text { Langsung }\end{array}$ & Pengaruh Total \\
\hline $\mathrm{pH}_{\mathrm{KCL}} \mathrm{T} \rightarrow$ DOA & 0,046 & 0,285 & 0,331 \\
$\mathrm{pH}$ KCL $\rightarrow$ pHA & 0,314 & 0,195 & 0,509 \\
$\mathrm{AlT} \rightarrow$ DOA & 0,863 & 0,876 & 1,739 \\
$\mathrm{AlT} \rightarrow$ pHA & $-0,426$ & $-0,339$ & $-0,765$ \\
$\mathrm{DOA} \rightarrow$ Produksi & $-0,367$ & $-0,362$ & $-0,729$ \\
$\mathrm{pHA} \rightarrow$ Produksi & $-0,245$ & 0,029 & $-0,216$ \\
$\mathrm{pH}$ KCLT $\rightarrow$ Produksi & 0,314 & 0,136 & 0,450 \\
$\mathrm{AlT} \rightarrow$ Produksi & $-0,426$ & $-0,551$ & $-0,977$ \\
\hline
\end{tabular}

Keterangan : $\mathrm{pH}_{\mathrm{KCL}} \mathrm{T}: \mathrm{pH}_{\mathrm{KCL}}$ tanah, AlT : Aluminium tanah, DOA: Oksigen terlarut air, dan pHA : pH air.

$\mathrm{pH}$ air adalah nilai dari pengukuran ion hidrogen $\left(\mathrm{H}^{+}\right)$di dalam air. Air dengan kandungan ion $\mathrm{H}^{+}$tinggi akan bersifat asam dan sebaliknya akan bersifat basa (alkali) (Nana dan Putra, 2008). Nilai pH air dengan rata-rata 9,433 memberikan pengaruh nyata $(\mathrm{P}<0,10)$ terhadap produksi total pada tambak polikultur udang vaname dan ikan bandeng di Kabupaten Lamongan dengan pengaruh langsung -0,245. Hal ini menunjukkan bahwa makin tinggi $\mathrm{pH}$ air maka produksi total akan mengalami penurunan. Rata-rata tingginya $\mathrm{pH}$ air tambak karena jenis tanahnya yang aluvial non sulfat masam dan kandungan bahan organik tanah relatif rendah. Kondisi $\mathrm{pH}$ air yang ideal bagi kehidupan dan pertumbuhan udang vaname adalah antara 7,5-8,5 (Haliman dan Adijaya, 2005) dan yang baik untuk pertumbuhan ikan bandeng pada $\mathrm{pH}$ air 7,0-8,5 (Ismail et al., 1993). Pada umumnya $\mathrm{pH}$ air yang baik bagi organisme akuatik adalah 6,5-9,0; pada pH 9,5-11,0 dan 4,0-6,0 mengakibatkan produksi rendah (Poernomo, 1988). Pada $\mathrm{pH}$ di bawah 4,5 atau di atas 9,0 ikan atau udang akan mudah sakit dan lemah serta nafsu makan menurun bahkan udang cenderung keropos dan berlumut. Apabila nilai $\mathrm{pH}$ yang lebih besar dari 10 akan bersifat letal bagi ikan maupun udang (Ahmad, 1991).

\section{KESIMPULAN}

Produksi total tambak polikultur udang vaname dan ikan bandeng di Kabupaten Lamongan dipengaruhi secara nyata oleh 2 peubah dari 15 peubah kualitas tanah dan 2 peubah dari 11 peubah kualitas air. Peubah kualitas tanah meliputi $\mathrm{pH}_{\mathrm{KCL}}$ tanah dengan pengaruh langsung sebesar 0,314 dan $\mathrm{Al}$ tanah sebesar -0,426, sedangkan peubah kualitas air meliputi DO dengan pengaruh langsung sebesar $-0,367$ dan $\mathrm{pH}$ air sebesar $-0,245$ terhadap produksi total.

\section{UCAPAN TERIMA KASIH}

Diucapkan banyak terima kasih kepada Hakim Madeng atas bantuannya dalam pengambilan sampel tanah di lapangan; Rohani, Andi Sahrijanna, Kurnia dan Gappar atas bantuannya dalam analisis air serta Rosiana Sabang, Rahmiyah dan Kamariah atas bantuannya dalam analisis kualitas tanah.

\section{DAFTAR PUSTAKA}

Adhikari, S. 2003. Fertilization soil and water quality management in small scale ponds: Fertilization require- 
ments and soil properties. $J$. Aquaculture Asia, 8(4):1-8.

Adiwijaya, D., S.R. Sapto, E. Sutikno, Sugeng, dan Subiyanto. 2003. Budidaya udang vaname Litopenaeus vannamei sistem tertutup yang ramah lingkungan. Departemen Kelautan dan Perikanan. Balai Besar Pengembangan Budidaya Air Payau Jepara. 29hlm.

Agus, F. Yusrial, dan Sutono. 2006. Penetapan tekstur tanah. Dalam: Kurnia et al. (eds.). Sifat fisik tanah dan metode analisisnya. Balai Besar Penelitian dan Pengembangan Sumberdaya Lahan Pertanian, Bogor. Hlm.:43-62.

Ahern, C.R., B. Blunden, L.A. Sullivan, and A.E. McElnea. 2004. Soil sampling, handling, preparation and storage for analisys of dried samples. In: Acid sulfate soils laboratory methods guidelines. Queensland Department of Natural Resources, Mines and Energy, Indooroopilly, Queensland, Australia, 1-5pp.

Ahmad, T. 1991. Pengelolaan peubah mutu air yang penting dalam tambak udang intensif. Infish Manual Seri No. 25. Direktorat Jenderal Perikanan bekerjasama dengan International Development Research Center. 40hlm.

Andriyanto, F., A. Efani, dan H. Riniwati. 2013. Analisis faktor-faktor produksi usaha pembesaran udang vanname Litopenaeus vannamei di Kecamatan Paciran Kabupaten Lamongan Jawa Timur; pendekatan fungsi cobb Douglass. J. ECSOFiM., 1(1):82-96.

Anonim. 2003. Litopenaeus vannamei sebagai alternatif budidaya udang saat ini. PT. Central Proteinaprima (Charoen Pokphand Group). Surabaya. 16hlm.

Anonim. 2010. Lamongan dalam angka 2010. Kerjasama Badan Pusat Statistik Kabupaten Lamongan dan
Pemerintah Daerah Kabupaten Lamongan, 371 hlm.

Anonim, 2012. Dampak negatif aluminium bagi lingkungan hidup. http://arsipperikanan.blogspot.com/2012/03/dam pak-negatif-aluminium-bagi.html.

[Diakses pada tanggal 17 September 2014].

Anonim. 2014. Minapolitan budidaya Kabupaten Lamongan. http://semilir. kkp.go.id/index.php/arsip/c/27/Minap olitan-Budidaya-Kab.-Lamongan/?ca tegory_id. [Diakses Tanggal 17 September 2014].

American Public Health Association (APHA). 2005. Standard methods for examination of water and wastewater. Twentieth edition APHAAWWA-WEF. Washington. 1185p.

Arsyad, H. dan S. Sanusi. 1990. Budidaya ikan bandeng (Chanos chanos Forsk.). INFIS Manual Seri No. 11. Dirjen Perikanan. Jakarta. 56hlm.

Blanco, G.J. 1970. Status and problem of coastal aquaculture in the Philippines. In: Pillay, T.V.R. (Ed), Coastal aquaculture in the Indo-Pasific Region. Fishing News (Books), London. 66-67pp.

Boyd, C.E. 1990. Water quality in ponds for aquaculture. Auburn University, Alabama. 482p.

Boyd, C.E. 1995. Bottom soils, sediment and pond aquaculture. Chapman and Hall. New York. 348p.

Boyd, C.E., C.W. Wood, and T. Thunjai. 2002. Aquaculture pond bottom soil quality management. Pond Dynamics/ Aquaculture Collaborative Research Support Program Oregon State University, Corvallis, Oregon. 41p.

Boyd, C.E. 2003. Applying effluent standard to small-scale shrimp farm. Aquaculture Certification Council: http://ceboyd@acesag.auburn.edu. (Diakses pada 12 Oktober 2007). 
Boyd, C.E. 2008. Pond bottom soil analyses. Global Aquaculture Advocate September/October. US. 92p.

Buwono, I.D. 1993. Tambak udang windu; Sistem pengelolaan berpola intensif. Kanisius Press. Yogyakarta. 151hlm.

Clifford, H.C. 1994. Semi-intensive sensation: A case study in marine shrimp pond management. World Aquaculture, 25(3):10.

Davis, M.L. and D.A. Cornwell. 1991. Introduction to environmental engineering. $2^{\text {nd }}$ ed. Mc-Graw-Hill, Inc. New York. 822p.

Draper, N.R. and H. Smith. 1981. Applied regression analysis. $2^{\text {nd }}$ ed. John Wiley \& Sons. New York. 709p.

Everitt, B.S. and G. Dunn. 2001. Applied multivariate data analysis. $2^{\text {nd }} \mathrm{ed}$. Arnold. London. 342p.

Eviati dan Sulaeman. 2009. Analisis kimia tanah, tanaman, air dan pupuk. Balai Penelitian Tanah. Balai Besar Litbang Sumberdaya Lahan Pertanian. Balitbang Pertanian. Bogor. 234hlm.

Haliman, R.W. dan D. Adijaya S. 2005. Udang vannamei, pembudidayaan dan prospek pasar udang putih yang tahan penyakit. Penebar Swadaya Press, Jakarta. $75 \mathrm{hlm}$.

Hanafi, A. 1990. Socio-economic and managerial profiles of brackishwater aquaculture in South Sulawesi. $J$. Perikanan Budidaya Pantai, 6(2):97114.

Hanafiah, K.A. 2005. Dasar-dasar ilmu tanah. Raja Grafindo Persada Press, Jakarta. 360hlm.

Handayanto, E. dan K. Hairiah. 2007. Biologi tanah. Landasan pengelolaan tanah sehat. Pustaka Adipura Press. Yogyakarta. 196hlm.

Hardjowigeno, S. 2002. Ilmu tanah. Akademika Pressindo Press. Jakarta. 283hlm.

Hidayanto, M., H.W. Agus, dan F. Yossita. 2004. Analisis tanah tambak sebagai indikator tingkat kesuburan tambak.
J. Pengkajian dan Pengembangan Teknologi Pertanian. Badan Riset Pertanian, Departemen Pertanian Indonesia, 6(4):98-109.

Ismail, A., A. Poernomo, P. Sunyoto, Wedjatmiko, Dharmadi, dan R.A.I. Budiman. 1993. Pedoman teknis usaha pembesaran ikan bandeng di Indonesia. Pusat Penelitian dan Pengembangan Perikanan, Jakarta. 93hlm.

Karthik, M., J. Suri, N. Saharan, and R.S. Biradar. 2005. Brackish water aquaculture site selection in Palghar Taluk, Thane District of Maharashtra, India, using the techniques of remote sensing and geographical information system. Aquacultural Engineering, 32:285-302.

Kementrian Lingkungan Hidup (KLH). 1988.

Keputusan Menteri Negara KLH tentang pedoman penetapan baku mutu lingkungan. KLH. Jakarta. 57hlm.

Liu, Z.J. 1985. Oxidation-reductin potensial in physical chemistry of paddy soil. Edited by $\mathrm{Yu}$ Tian-Ren. Science Press. Beijing. 208p.

Malone, R.F. and D.G. Burden. 1988. Design of recilculating bluecrab shedding system. Louisiana Sea Grand College Program. Center for Wetland Recources Louisiana State University. US. 76p.

Mangampa, M. dan E.A. Hendradjat. 2014. Pengembangan budidaya udang vaname (Litopenaeus vannamei) pola ekstensif plus di lahan marginal. Laporan Hasil Penelitian. Balai Penelitian dan Pengembangan Budidaya Air Payau. Maros. 12hlm.

Mansyur, A. 2007. Peningkatan produktivitas tambak melalui polikultur udang vanamei dan ikan bandeng. Dalam: Purnomo et al. (ed.). Prosiding Akuakultur 2007. Masyarakat Akuakultur Indonesia (MAI). Surabaya, 57 Juni 2007. Hlm.:201-208. 
Menon, R.G. 1973. Soil and water analysis: A laboratory manual for the analysis of soil and water. Proyek Survey O.K.T. Sumatera Selatan, Palembang. $190 \mathrm{p}$.

Mintardjo, K., A. Sunaryanto, Utaminingsih, dan Hermiyaningsih. 1985. Persyaratan tanah dan air. Dalam: Pedoman budidaya tambak udang, Deirektorat Jenderal Perikanan, Departemen Pertanian, Jakarta. Hlm.:63-111.

Mudjiman, A. 1986. Budidaya ikan di sawah tambak. CV. Simplex Press, Jakarta. 122hlm.

Muir, J.F. and J.M. Kapetsky. 1988. Site selection decisions and project cost: the case of brackish water pond systems. In: Aquaculture engineering technologies for the future. hemisphere publishing corporation, New York. 45-63pp.

Murachman. 2002. Identifiksi sifat fisik, kimia dan biologi sumberdaya lahan tambak dan lingkungannya dalam hubungannya dengan kesesuaian sistem budidaya di Kabupaten Sidoarjo. J. Ilmu-ilmu Hayati, 14(1): $1-10$.

Mustafa, A. dan E. Ratnawati. 2005. Faktor pengelolaan yang berpengaruh terhadap produksi rumput laut (Gracilaria verrucosa) di tambak tanah sulfat masam (studi kasus di Kabupaten Luwu, Provinsi Sulawesi Selatan). J. Penelitian Perikanan Indonesia, 11(7):67-77.

Mustafa, A. dan E. Ratnawati. 2007. Faktorfaktor dominan yang mempengaruhi produktivitas tambak di Kabupaten Pinrang, Sulawesi Selatan. J. Riset Akuakultur, 2(1):117-133.

Mustafa, A., Rachmansyah dan A. Hanafi. 2007. Kelayakan lahan untuk budidaya perikanan pesisir. Dalam: Kumpulan makalah bidang riset perikanan budidaya. Disampaikan pada simposium kelautan dan perikanan pada tanggal 7 Agustus 2007 di Gedung Bidakara, Jakarta. Pusat Riset Perikanan Budidaya, Jakarta. 28hlm.

Mustafa, A. and J. Sammut. 2007. Effect of different remediation techniques and dosages of phosphorus fertilizer on soil quality and klekap production in acid sulfate soil-affected aquaculture ponds. Indonesian Aquaculture J., 2(2):141-157.

Mustafa, A., M. Paena, Tarunamulia, dan J. Sammut. 2008. Hubungan antara faktor kondisi lingkungan dan produktivitas tambak untuk penajaman kriteria kesesuaian lahan. 2 . Kualitas tanah. J. Riset Akuakultur, 3(1):105-121.

Mustafa, A. and J. Sammut. 2010. Dominant factors effecting seaweed (Gracilaria verrucosa) production in acid sulfate soils-affected ponds of Luwu Regency, Indonesia. Indonesian Aquaculture J., 5(2):147-162.

Mustafa, A. dan A. Athirah. 2014. Aplikasi analisis jalur dalam penentuan pengaruh kualitas tanah dan air terhadap produksi total tambak di Kabupaten Demak, Provinsi Jawa Tengah. J. Kelautan Nasional, 9(2): 65-79.

Nana, S.S. dan U. Putra. 2008. Manajemen kualitas tanah dan air dalam kegiatan perikanan budidaya. Balai Budidaya Air Payau, Takalar. Dirjen Perikanan Budidaya Departemen Kelautan dan Perikanan. 27hlm.

Pantjara, B., M. Mangampa dan Rachmansyah. 2010. Budidaya udang windu, Penaeus monodon pada tambak tanah sulfat masam di Tarakan, Kalimantan Timur. $J$. Perikanan, 12(1):1-10.

Poernomo, A. 1988. Pembuatan tambak udang di Indonesia. Seri pengembangan No. 7. Balai Penelitian Perikanan Budidaya Pantai, Maros. 40hlm. 
Poernomo, A. 1992. Pemilihan lokasi tambak udang berwawasan lingkungan. Seri pengembangan hasil penelitian No. $\mathrm{PHP} / \mathrm{Kan} / \mathrm{Patek} / 004 / 1992$. Indonesia. 40hlm.

Ponnamperuma, F.N. 1978. Electrochemical changes in submerged soils. In: Soil and rice. International Rice Research Institute, Los Banos. Philipines. 421441pp.

Ranoemihardjo, B.S., S. Bambang, dan I. Lantang. 1985. Pupuk dan pemupukan tambak. Direktorat Jenderal Perikanan. Jakarta. Hlm.185-207.

Riduwan dan E.A. Kuncoro. 2008. Cara menggunakan dan memaknai analisis jalur (PATH ANALYSIS). Cetakan kedua. Alfabeta Press. Bandung. $282 \mathrm{hlm}$.

Rutherford, R.D. and M.K. Choe. 1993. Statistical model for causal analysis. John Wiley \& Sons, Inc., New York. $216 \mathrm{p}$.

Salam, M.A., L.G. Ross, and C.M.M. Beveridge. 2003. A comparison of development opportunities for crab and shrimp aquaculture in southwestern Bangladesh, using GIS modeling. Aquaculture, 220:477-494.

Sarwono, J. 2007. Analisis jalur untuk riset bisnis dengan SPSS. Andi Press. Yogyakarta. 321hlm.

Stickney, R.R. 1979. Principles of warmwater aquaculture. A Wiley Interscience Publication, John Wiley $\&$ Sons. New York. 371p.

Subroto. 2003. Tanah, pengelolaan dan dampak. Fajar Gemilang Press. Samarinda. 194hlm.

Sudradjat, A. dan Wedjatmiko. 2010. Budidaya udang di sawah dan tambak. Penebar Swadaya Press. Jakarta. 74hlm.
Suliyanto. 2011. Ekonometrika terapan: Teori \& aplikasi dengan SPSS. Andi Press. Yogyakarta. 311hlm.

Supranto, J. 2004. Analisis multivariat: Arti dan interpretasi. Cetakan pertama. Rineka Cipta Press. Jakarta. 359hlm.

Suprapto. 2005. Petunjuk teknis budidaya udang vannamei (Litopenaeus vannamei). CV Biotirta. Bandar Lampung. 25hlm.

Sutrisyani dan S. Rohani. 2009. Panduan praktis analisis kualitas air payau. Cetakan kedua. Pusat Riset Perikanan Budidaya. Jakarta. 55hlm.

Swastika, J. 2001. Pengamatan laju dekomposisi bahan organik pada proses pengeringan tanah dasar tambak. Balai Budidaya Lampung. 227hlm.

Tarigan, M.S dan Edward. 2003. Kandungan total zat padat tersuspensi (Total Suspended Solid) di Perairan Raha, Sulawesi tenggara. Makara Sains, 7(3):109-119

Taufiqull, H. 2016. Kadar dan kelarutan oksigen. https://www.tneutron.net/ blog/kadar-dan-kelarutan-oksigen/. [Diakses tanggal 12 April 2017].

Treece, G.D. 2000. Site selection. In: Stickney (eds.). Encyclopedia of aquaculture. John Wiley dan Sons, Inc.. New York. 869-879pp.

Wardoyo, S.T.H. 1982. Kriteria kualitas air untuk keperluan pertanian dan perikanan. ANDAL PPLH-PUSDIPSL.IPB. Bogor. 50hlm.

Widarjono, A. 2010. Analisis statistika multivariat terapan. Edisi pertama. UPP STIM YKPN, Yogyakarta. 358hlm.
Diterima
: 21 Juni 2017
Direview
: 02 Juli 2017
Disetujui
: 23 Maret 2018 
